\title{
A new species of velvet mite from meridional South America of the genus Clavismaris (Acari, Erythraeoidea, Smarididae, Hirstiosomatinae)
}

\author{
Ana Paula Ott' (1D https://orcid.org/0000-0002-5296-6240 \\ Ricardo Ott ${ }^{2}$ (1) https://orcid.org/0000-0001-7392-1415
}

\author{
1. Departamento de Fitossanidade, Faculdade de Agronomia, Universidade Federal do Rio Grande do Sul. Av. Bento Gonçalves, 7712, 91540-000, \\ Porto Alegre, RS, Brazil. (ana.ott@ufgrs.br). \\ 2. Museu de Ciências Naturais, Fundação Zoobotânica do Rio Grande do Sul. Rua Dr. Salvador França, 1427, 90690-000, Porto Alegre, RS, Brazil. (rott@fzb.rs.gov.br).
}

Received 12 January 2018

Accepted 11 April 2018

Published 11 June 2018

DOI 10.1590/1678-4766e2018011

\begin{abstract}
A new species of Clavismaris Southcott, 1963 is described from the southern limit of distribution of the Brazilian Atlantic Forest at Rio Grande do Sul state, Brazil. The specimens were collected by pyrethroid tree canopy fogging in preserved mountain slopes forests areas around $120 \mathrm{~m}$ of altitude.
\end{abstract}

KEYWORDS. Acarology, Taxonomy, Neotropical, new species, Brazil.

RESUMO. Descrição de uma espécie nova de ácaro aveludado do gênero Clavismaris da América do Sul meridional (Acari, Erythraeoidea, Smarididae, Hirstiosomatinae). É descrita uma espécie nova de Clavismaris Southcott, 1963 do limite sul de distribuição da Mata Atlântica brasileira no estado do Rio Grande do Sul, Brasil. Os espécimes foram coletados com nebulização de copas de árvores por piretróide em florestas preservadas de encosta de montanha numa altitude de cerca de $120 \mathrm{~m}$.

PALAVRAS-CHAVE. Acarologia, Taxonomia, Neotropical, espécie nova, Brasil.

Smaridid mites are moderately large and worldwide distributed predator mites found mainly in litter and grassland habitats being the larva of some species parasites of insects (Krantz \& WaLter, 2009).

According to Beron (2008) and MAKOL \& WoHLTMANN (2012), there is only one endemic smaridid species registered for South America, actually Smaris nicoleti (Gervais, 1849) from Chile. Although dubious (see BERON, 2008:55), there is another record of a Smarididae to South America, actually the european species Hirstiosoma ampulligera (Berlese, 1887). The species is registered for several South American countries (Argentina, Brazil, Paraguay, and Chile). However, the above cited distribution of the species for South America is not listed or commented by WoHLTMANN (2010) or MaKol \& Wohltmann (2012).

Clavismaris was proposed by Southcotт (1963) to include C. conifera Southcott, 1963 and C. cybaea Southcott, 1963, described respectively from Mexico and USA. The same author above considered Clavismaris close to the New World Trichosmaris Southcott, 1963 and to the Australian Sphaerotarsus Womersley, 1936, differing from the first by the clavate shape of the posterior cristal sensilla and from the second by the less enlarged tarsus IV of males.
The material included in this paper was collected by canopy fogging at the southern limit of the Brazilian Atlantic Forest and represents the second Smaridid and for now the first known species of Clavimaris from South America.

Based on morphological and morfometrical data we conclude that the examined specimens belong to an undescribed species of Clavismaris and are herein presenting the description of this new species.

\section{MATERIAL AND METHODS}

Examined material is deposited at the Acarological collection of the Museu de Ciências Naturais da Fundação Zoobotânica do Rio Grande do Sul (MCN). The specimens were collected on tree canopies using pyrethroid fogging, preserved in ethanol $80 \%$ and posteriorly mounted in slides with Hoyer's medium according to JEPPSON et al. (1975).

Descriptions follow Southсотт (1963) with modifications and SouTHCOTT (1961) for abbreviations used in text. Images were taken at optical microscope and image layers were fused using Helicon Focus software (KozUB et al., 2012). All measurements are in micrometers $(\mu \mathrm{m})$. 


\section{RESULTS}

\section{Clavismaris maquine sp. nov.}

(Figs 1-15)

urn:lsid:zoobank.org:act:2D97B81A-10C9-49AB-B516A7F426127A58

Type material. Holotype $q$ from Atlantic forest area at FEPAGRO Maquiné, Rio Grande do Sul, Brasil
(29`39'45.17’S, 50¹3’28.05’W), 10-12.I.2006, Equipe Fogging MCN leg., deposited at MCN ARA 1912. Paratype. $ठ$ same locality and collector of holotype, 24-26.IV.2006 (MCN ARA 1913).

Additional examined material. $\delta$ (MCN ARA 1914), ๆ (MCN ARA 1915), $q$ (MCN ARA 1916), ( (MCN ARA 1919), + (MCN ARA 1920), all same date holotype; + , 1820.VII.2006 (MCN ARA 1917); 우 (MCN ARA 1918), ㅇ
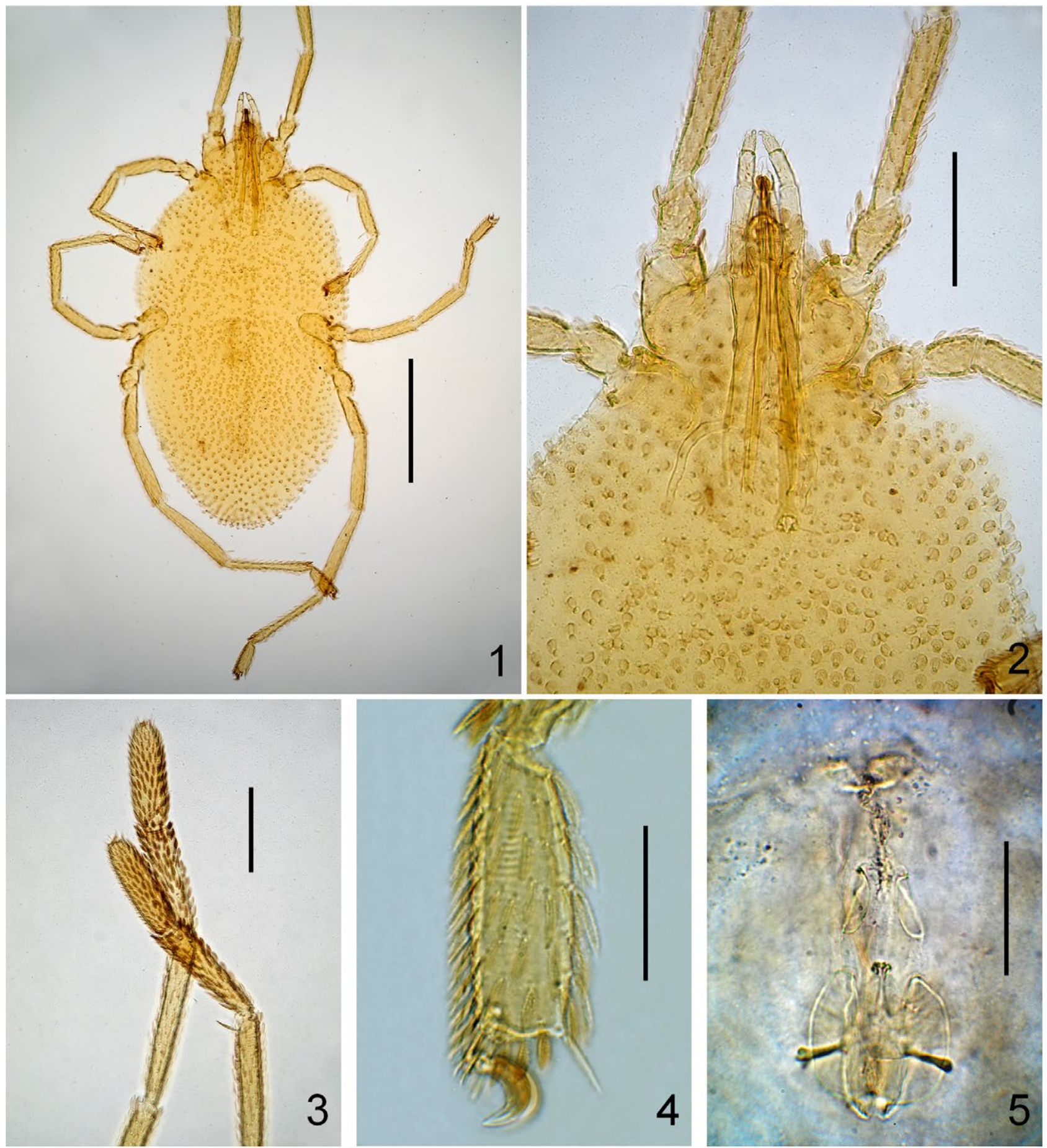

Figs 1-5. Clavismaris maquine sp. nov., holotype $q$ (MCN ARA 1912): 1, body, dorsal; 2, gnathosoma and propodossoma, dorsal; 3, tarsi, legs I, lateral; 4, tarsus, leg IV, lateral; 5, genital region, dorsal. Scale bars: Fig. 1, $500 \mu \mathrm{m}$; Figs 2, 3, $200 \mu \mathrm{m}$; Figs 4, 5, $100 \mu \mathrm{m}$. 
(MCN ARA 1921), both 10-12.X.2006; all same locality and collectors as holotype.

Etymology. The specific name is taken from the typelocality, Maquiné, Rio Grande do Sul, Brazil.

Diagnosis. Clavismaris maquine sp. nov. differs from C. cybaea by the number of nasu scobalae, being 11-12 in males, 14-18 in females and eight in the last species. On the other hand, the number of nasu scobalae in the new species is similar to the number present at $C$. conifera (17); however the new species differs from the last one in the number of dorsal spicules on the nasu scobalae, being around 20 in $C$. maquine sp. nov. (Fig. 14) and 6-8 in C. conifera (Soutнсотт, 1963:235). Based on females data, the combined measures of C. maquine sp. nov. ISD $(340-460 \mu \mathrm{m})$ and the ratio of the tibia/genu IV (1.15-1.22) are confirmatory characters for the species, being respectively $381 \mu \mathrm{m}$ and 0.85 in $C$. conifera (only the holotype available) and $267 \mu \mathrm{m}$ and 1.00-1.02 in
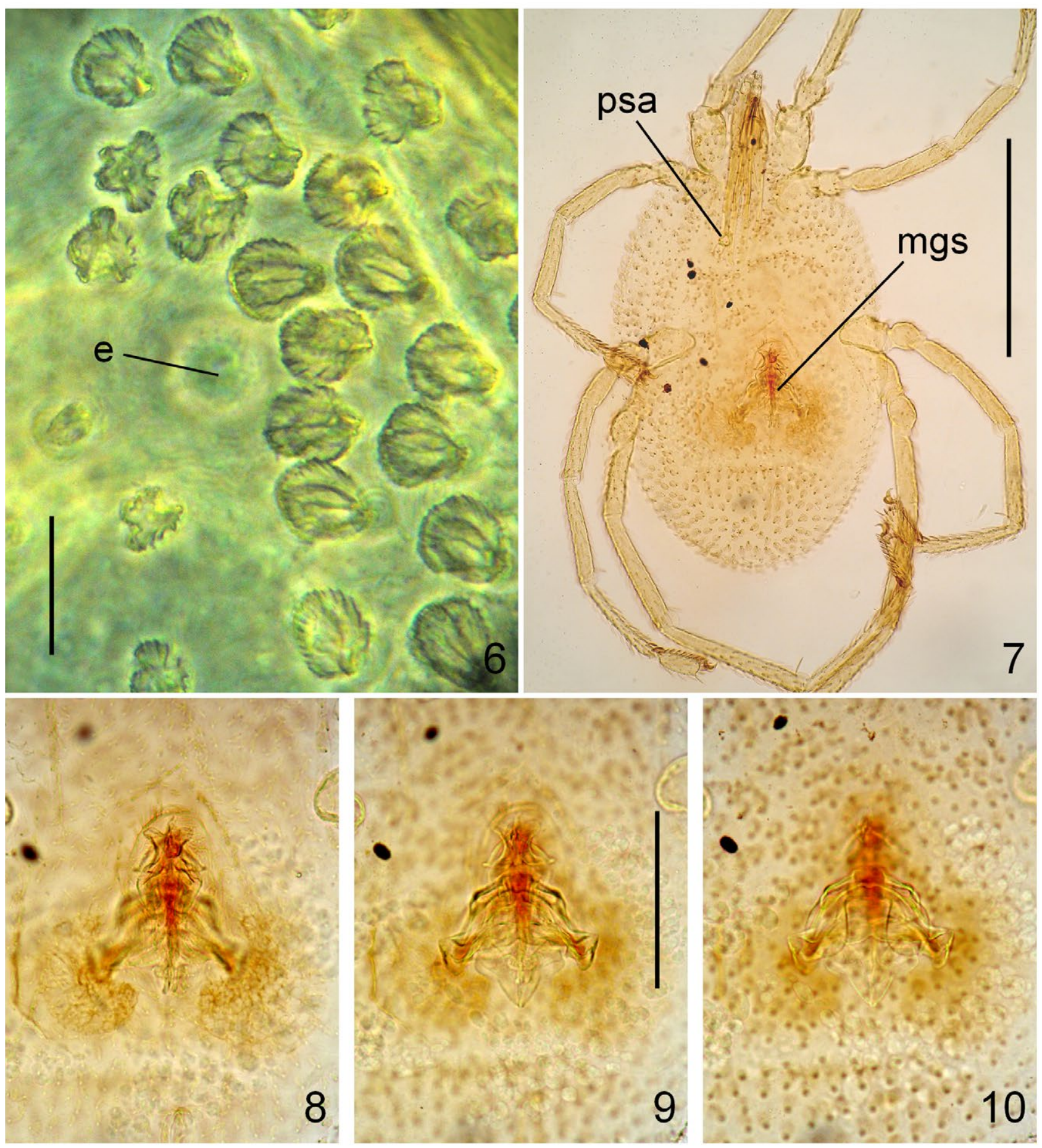

Figs 6-10. Clavismaris maquine sp. nov. Female holotype $\odot$ (MCN ARA 1912): 6, eye region and surrounding scobalae. Paratype $\widehat{\delta}$ (MCN ARA 1913): 7, idiosoma, ventral view; 8-10, genital sclerite in ventral view, respectively from distal plan to proximal plan of view (e, eye; mgs, male genital sclerite; psa, posterior sensillary area). Scale bars: Fig. 6, $50 \mu \mathrm{m}$; Fig. 7, 500 $\mu \mathrm{m}$; Figs 8-10, $200 \mu \mathrm{m}$. 
C. cybaea (although only two males measure data available) sensu SouthcotT (1963).

Description. Female holotype (MCN ARA 1912). Color in life unknown. Specimen of normal smaridid shape (Fig. 1) also with a normal nasus (Figs 1,2). Idiosoma $1758 \mu \mathrm{m}$ long, $928 \mu \mathrm{m}$ wide.

Gnathosoma normal, with normal armilla. Palpi with dorsal needle-like setae. Mouth cone poorly ciliated; setae tapering, pointed.

Crista linear normal (Figs 11, 14, 15). Anterior sensillary area of crista with two ciliated clavate sensillae (Figs 11, 14), nasus with 17 strongly spiculated scobalae, about 2-3 times long as wide, 21-36 $\mu \mathrm{m}$ long. Posterior sensillary area with two ciliated clavate sensillae (Figs 11, 15). Crista extends $48 \mu \mathrm{m}$ behind centre of PSens. The standard data are: ASens 19, PSens 52, SBa 16, SBp 17, ISD 430, DS 19-26.

Eyes one on each side, cornea $24 \mu \mathrm{m}$ across, but with surrounding part included the eye is $36 \mu \mathrm{m}$ across (Fig. 6). Line joining centres of eyes is $20 \mu \mathrm{m}$ anterior to the midpoint of ISD $(\mathrm{OAS}=240 \mu \mathrm{m}, \mathrm{OPS}=260 \mu \mathrm{m})$.

Dorsal idiosomal scobalae lightly chitinized, variable shaped and typically smaridid. Nasus with 17 scobalaee forming an oblong or oval band with five tectal projecting columns of spicules, two being along the tectal borders, and three placed in a paramedian situation along the setae
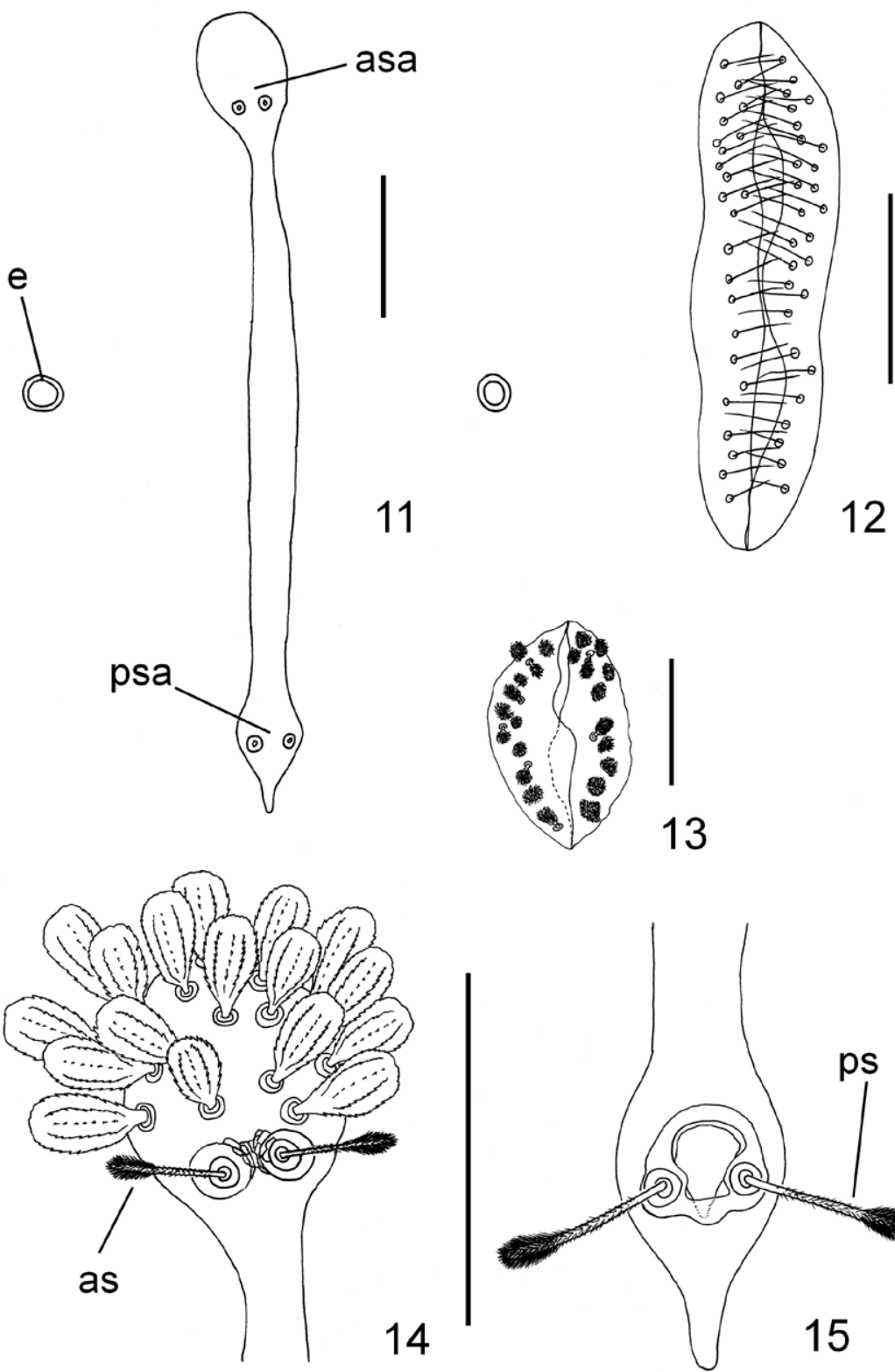

13

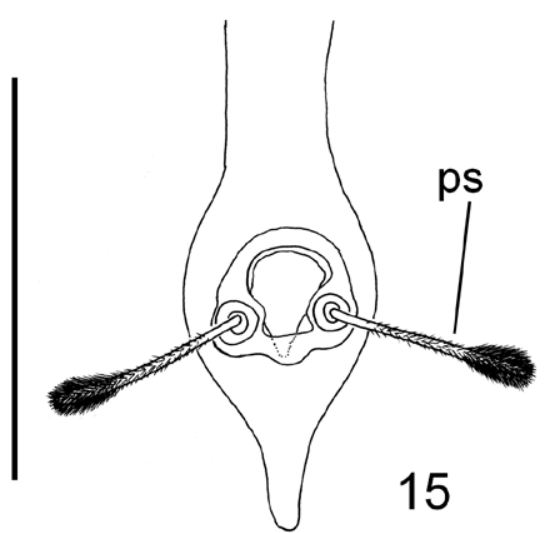

Figs 11-15. Clavismaris maquine sp. nov. Figs 11, 14, 15, female $q$ (MCN ARA 1912); Figs 12, 13, $q$ (MCN ARA 1915): 11, dorsal scutum (only base of sensillary setae indicated); 12, genital opening; 13 , anal opening; 14, anterior sensillary area; 15 , posterior sensilary area (asa, anterior sensillary area;

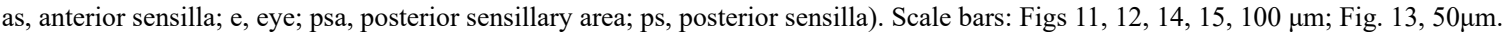


comprising together abouth 16-20 spicules. The appearance of the dorsal scobalae strongly prismatic depending of view (Fig. 6).

Ventral surface normal, the central ventralae smaller, bushy with longer ciliations. External genital plates covered with 20-30 needle like setae (Fig. 12). Internal genitalia region with characteristic shape showing an anterior pair of sclerotized plates, a median narrow sclerotized structure and a posterior rounded sclerotized area bearing two oblique inserted narrow and heavier sclerotized processes (Fig. 5). External genitalia $202 \mu \mathrm{m}$ long. Anus oval, $80 \mu \mathrm{m}$ long, $47 \mu \mathrm{m}$ wide. Anal valves covered with around ten pairs of heavy ciliated ventralae, usually something smaller as remaining surrounding ventralae (Fig. 13).

Legs normal. Legs lengths (inclusive trochanter-tips of tarsal claws): I $1750 \mu \mathrm{m}$, II $980 \mu \mathrm{m}$, III $1070 \mu \mathrm{m}$, IV $1680 \mu \mathrm{m}$. Tarsus I $250 \mu \mathrm{m}$ long, $80 \mu \mathrm{m}$ wide; tibia I $390 \mu \mathrm{m}$ long; genu I $390 \mu \mathrm{m}$ long; tarsus IV $190 \mu \mathrm{m}$ long, $60 \mu \mathrm{m}$ wide; tibia IV $410 \mu \mathrm{m}$ long; genu IV $340 \mu \mathrm{m}$ long. Following ratios derived: taI/tiI 0.64; tiI/geI 1.00; taIV/ tiIV 0.46; tiIV/geIV 1.21. Tarsus IV not strongly enlarged (Figs 1,4). Setae of legs typically smaridid, scobale almost as strong as ventralae, well covered with spicules, setae on distal parts of segments tending to be more elongated and flattened (Figs 3, 4). Claws I-IV well covered with short pilosity in the basal three quarters (Fig. 4).

Females variations $(n=8)$. Number of nasus scobalae 14-18; ISD 340-460 $\mu \mathrm{m}$; Tibia 340-440 $\mu \mathrm{m}$ and genu 270-360 $\mu \mathrm{m}$ IV; ratio ti/ge IV 1.15-1.22.

Male. Paratype (MCN ARA 1913; Fig. 7). As female except noted. Idiosoma $1090 \mu \mathrm{m}$ long, $600 \mu \mathrm{m}$ wide.

Nasus with 11 strongly spiculated scobalae, crista extends $36 \mu \mathrm{m}$ behind centre of PSens. The standard data are: ASens $19 \mu \mathrm{m}$, PSens $38 \mu \mathrm{m}$, SBa $7 \mu \mathrm{m}$, SBp $12 \mu \mathrm{m}$, ISD 345, DS 19-26.

Eyes one on each side, cornea $19 \mu \mathrm{m}$ across, but with surrounding part included the eye is $26 \mu \mathrm{m}$ across. Line joining centres of eyes is $10 \mu \mathrm{m}$ anterior to the midpoint of ISD $(\mathrm{OAS}=150 \mu \mathrm{m}, \mathrm{OPS}=200 \mu \mathrm{m})$.

Internal genitalia clearly of male type; presenting a central column of sinuose sides and a central inverted " $\mathrm{V}$ " shaped sclerotized structure (Figs 7-10); in ventral portion is also possible to observe a paired oval sac-like structure (Fig. 10). External genitalia $200 \mu \mathrm{m}$ long. Anus oval, $60 \mu \mathrm{m}$ long, $40 \mu \mathrm{m}$ wide.

Legs lengths (inclusive trochanter-tips of tarsal claws): I $1600 \mu \mathrm{m}$, II $910 \mu \mathrm{m}$, III $1000 \mu \mathrm{m}$, IV $1460 \mu \mathrm{m}$.
Tarsus I $200 \mu \mathrm{m}$ long, $60 \mu \mathrm{m}$ wide; tibia I $370 \mu \mathrm{m}$ long; genu I $340 \mu \mathrm{m}$ long; tarsus IV $160 \mu \mathrm{m}$ long, $40 \mu \mathrm{m}$ wide; tibia IV $350 \mu \mathrm{m}$ long, genu IV $290 \mu \mathrm{m}$ long. Following ratios derived: taI/tiI 0.54; tiI/geI 1.09; taIV/tiIV 0.46; tiIV/geIV 1,21.

Males variations $(n=2)$. Number of nasus scobalae 11-12; ISD 345-400; TibiaIV 350-380 and genu IV 290-330; ratio ti/ge IV 1.15-1.23.

Remarks. The number of nasus scobalae in males (11-12) of C. maquine sp. nov. is lower as in females (14-18). The number of nasus scobalae was only provided for the female holotype of $C$. conifera (17) and the male holotype of C. cybea (8) (SouthCOTт, 1963). However in the original description of the last species an additional male paratype and female were described, this character was not presented for any of them by the author. In this way, it could be expected that $C$. cybaea females would have large numbers of nasus scobalae, the opposite is expected regarding unknown males of $C$. conifer sp. nov..

Natural history. Species was collected at tree canopies in the Brazilian Atlantic Forest.

Distribution. Known only for the type-locality, Maquiné, Rio Grande do Sul, Brazil.

Acknowledgements. To the MCN colleagues Aline Barcellos, Eduardo Borsato, Ingrid Heydrich and Luciano Moura for the friendship, support and tireless field work during the fogging project (2005-2006). To Fundação Estadual de Pesquisa Agropecuária (FEPAGRO) for allowing the use of the area and facilities at Maquiné, RS. This work was supported by CNPq grant "Edital Universal” process \#474292/2004-5.

\section{REFERENCES}

Beron, P. 2008. Acarorum Catalogus 1. Acariformes: Calyptostomatoidea (Calyptostomatidae), Erythraeoidea (Smarididae, Erythraeidae). Sofia, Pensoft \& National Museum of Natural History. 272p.

Jeppson, L. R.; KeIfer, H. H. \& BAKer, E. W. 1975. Mites injurious to economic plants. Berkeley, University of California. 641p.

Kozub, D.; Khmelik, K.; Shapoval, J.; Chentsov, V.; Litovschenko, B. \& Starikh, V. 2012. Helicon Focus 5.3. Helicon Focus Ltd. Available at $<$ http://cybercom.net/ dcoffin/dcraw/>. Accessed on 23 May 2013.

Krantz, G. W. \& Walter, D. E. 2009. A Manual of Acarology. 3ed. Lubbock, Texas Tech University Press. 807p.

MąKol, J. \& Wohltmann, A. 2012. An Annotated Checklist of Terrestrial Parasitengona (Actinotrichida: Prostigmata) of the World, Excluding Trombiculidae and Walchiidae. Annales Zoologici 62(3):359-562.

Soutнсотт, R. V. 1961. Studies on the systematics and biology of the Erythraeoidea (Acarina), with a critical revision of the genera and subfamilies. Australian Journal of Zoology 9:367-610.

Southсотт, R. V. 1963. The Smarididae (Acarina) of North and Central America and some other countries. Transactions of the Royal Society of South Australia 86:159-245.

Wohltmann, A. 2010. Notes on the Taxonomy and Biology of Smarididae (Acari: Prostigmata: Parasitengona). Annales Zoologici 60(3):355-381. 